Scientific note

\title{
A scientific note on the characteristics of thyme honey from the Greek island of Kithira
}

\author{
Angeliki Tsigouri ${ }^{\mathrm{a} *}$, Maria Passaloglou-Katrali ${ }^{\mathrm{b}}$ \\ ${ }^{a}$ Institute of Veterinary Research of Athens, National Agricultural Research Foundation, \\ Neapoleos 25, 15310 Aghia Paraskevi, Attiki, Greece \\ b Cooperative of the Beekeepers' Association of South Greece, Makriyianni 57, 14343 N. \\ Chalkidona, Attiki, Greece
}

(Received 21 July 1999; revised 15 December 1999; accepted 22 January 2000)

\section{Thymus / honey / Greece / pollen analysis / diastase / invertase}

Greek thyme (Thymus) honey has been famous since antiquity for its special aroma and flavour [4]. It is produced from plants of the Lamiaceae family, that are found in Southern Greece and on the islands, and it represents $10 \%$ of the Greek honey crop [17]. The island of Kithira, with an area of $284 \mathrm{~km}^{2}$, is located at the south of the Peloponnese (latitude $36^{\circ} 08^{\prime} \mathrm{N}$, longitude $23^{\circ} 01^{\prime} \mathrm{E}$ ) and is covered by pine forests and moorland areas where Lamiaceae are abundant. The honey produced in the island (25 metric tons per year) is regarded as one of the best Greek thyme honeys. The objective of this study was to record the microscopic and physicochemical characteristics of this honey.

Twenty fresh unpasteurised samples, representing honey from all the thyme honey producers of the island in 1997, were analysed. All samples had the organoleptic characteristics of thyme honey. They were kept at $6{ }^{\circ} \mathrm{C}$ and analysed within 1 month. Melissopalynological analysis was carried out according to Louveaux et al. [9], without acetolysis, and we used Neubauer slides (Lilnck, Germany) for pouring a known volume of the sediment suspension. Pollen grains were counted and identified over the counting chamber of the Neubauer slide $(0.8 \mu \mathrm{L})$. Each sample was analysed in duplicate and $>600$ grains were examined for each replicate. The physicochemical analyses were performed according to methods recommended by the European Honey Commission [3].

Thyme pollen represented a mean of $42 \%$ of the pollen spectrum, with a range of 18 to $80 \%$ (Tab. I). Thyme honey is generally regarded as having under-represented pollen $[10,13,15]$. However, in Greece and especially in the islands, the percentage of thyme pollen can be as high as $85-90 \%[5,17]$. No fungal spores were found, as the pine trees in Kithira are not attacked by Marchalina hellenica. Pollen concentration ranged from 5000 to 85000 pollen grains per $10 \mathrm{~g}$ of honey, with an average of 29000 .

Thyme honey from Kithira had an average moisture content of $15.7 \%$ (range 14.7-17.9\%) which is in agreement with previously reported values [2, 17], though Drimjias and Karabournioti $[5,8]$ reported higher values. The electrical conductivity ranged from $0.25-0.50 \mathrm{mS} / \mathrm{cm}$ (mean 0.39), which is similar to the range reported for Greek thyme honey [17] as well as Italian thyme honeys [13]. Drimjias and Karbournioti [5, 8] recorded slightly higher values, but these values refer to a $20 \%$ solution of honey and not to a $20 \%$ solution of dry matter. The proline content averaged $1105 \mathrm{mg} / \mathrm{kg}$ (range 306-1 $873 \mathrm{mg} / \mathrm{kg}$ ), which was higher than that reported in previous studies $[8,17]$, while diastatic values averaged 18.9 DN (range: $10.3-32.4 \mathrm{DN}$ ) and were slightly lower than previously reported values for Greek $[5,8,17]$ or Italian thyme honey $[11,12-14]$. Finally, invertase activity ranged from 4.2-29.0 IN (mean 15.3 ), which is similar to the values found by Persano Oddo et al. [14] and lower than those reported by Karabournioti and Drimjias [8]. Correlation analysis was conducted on the data for the 20 samples, i.e., on the proportion of thyme pollen, the proportion of Lamiaceae pollen, pollen concentration, and all the values from the physico-chemical analysis. The only correlations that were found to be significant were between electrical conductivity and invertase activity $(r=0.761 ; P<0.01)$ and between diastase and

* Correspondence and reprints. E-mail: tsigouri.ivra@ nagref.gr 
Table I. Pollen spectrum of 20 samples of thyme honey from Kithira, Greece.

\begin{tabular}{|c|c|c|c|c|c|c|c|c|c|c|c|c|c|}
\hline \multicolumn{14}{|c|}{ Frequency of occurrence of the main pollen types $(\%)^{*}$} \\
\hline Thyme** & $\begin{array}{c}\text { Other } \\
\text { Lamiaceae }{ }^{* * *}\end{array}$ & $\begin{array}{l}\text { Trifolium } \\
\text { spp. }\end{array}$ & $\begin{array}{l}\text { Rubus } \\
\text { spp. }\end{array}$ & $\begin{array}{c}\text { Pistacia } \\
\text { lentiscus L. }\end{array}$ & $\begin{array}{l}\text { Eucalyptus } \\
\text { spp. }\end{array}$ & Asteraceae & $\begin{array}{l}\text { Cistus } \\
\text { spp. }\end{array}$ & $\begin{array}{l}\text { Erica } \\
\text { spp. }\end{array}$ & $\begin{array}{l}\text { Prunus } \\
\text { spp. }\end{array}$ & Apiaceae & $\begin{array}{l}\text { Asphodelus } \\
\text { spp. }\end{array}$ & Brassicaceae & $\begin{array}{l}\text { Convolvulus } \\
\text { spp. }\end{array}$ \\
\hline 80 & 15 & - & 2 & 3 & - & - & - & - & - & - & - & - & - \\
\hline 80 & 5 & - & - & - & - & - & 15 & - & - & - & - & - & - \\
\hline 80 & 2 & - & 15 & 3 & - & - & - & - & - & - & - & - & - \\
\hline 60 & 18 & _- & 12 & - & 7 & - & _ & - & - & 3 & - & _- & _- \\
\hline 60 & 13 & - & 3 & 14 & - & - & - & 3 & 7 & - & - & - & - \\
\hline 60 & 8 & - & 3 & 2 & - & 12 & 15 & - & - & - & - & - & - \\
\hline 60 & 8 & - & 3 & - & 3 & - & 2 & 24 & _ & _- & _- & - & - \\
\hline 40 & 35 & 8 & 1 & - & 8 & - & - & 5 & 3 & - & - & - & - \\
\hline 40 & 32 & - & 3 & 2 & 3 & - & 11 & 2 & - & - & - & 7 & - \\
\hline 40 & 31 & _- & - & 15 & - & - & _ & - & - & 14 & _- & - & _ \\
\hline 40 & 16 & - & 7 & 1 & 3 & 2 & 8 & - & 14 & - & 4 & 5 & - \\
\hline 40 & 13 & 15 & 13 & 2 & 2 & 15 & - & - & - & - & - & - & - \\
\hline 25 & 22 & 19 & 3 & 2 & 11 & 1 & 8 & - & 2 & 1 & 6 & - & - \\
\hline 22 & 37 & 26 & - & - & - & - & - & - & - & - & - & - & 15 \\
\hline 20 & 34 & - & 20 & 8 & 10 & - & 8 & - & - & - & - & - & - \\
\hline 20 & 30 & _- & 35 & 12 & 3 & _ & - & - & _ & - & _- & _- & _ \\
\hline 20 & 28 & 18 & - & - & 8 & 7 & 10 & 4 & 5 & - & _- & _- & _- \\
\hline 20 & 27 & - & 12 & - & 3 & - & 4 & 18 & 4 & 10 & - & - & 2 \\
\hline 20 & 26 & 18 & 2 & - & 10 & 5 & - & - & 2 & - & - & 17 & - \\
\hline 18 & 33 & 9 & 2 & 1 & - & 2 & 12 & 2 & 2 & 1 & - & 18 & - \\
\hline
\end{tabular}

* Only pollen types which accounted for $\geq 1 \%$ of the total are listed. The values are the average of 2 examinations of $\geq 600$ grains each. '-' indicates that the pollen type was not found or its frequency of occurrence was $<1 \%$.

** Coridothymus capitatus L. *** Salvia spp., Origanum spp., Rosmarinus officinalis L. and Satureia spp.

invertase activities $(r=0.484 ; P=0.03)$. Low correlation coefficients between invertase and diastase activities $(r=0.291$ for capped honey and $r=0.572$ for uncapped honeys) have also been reported by Sporns et al. [16], while others have found higher coefficients ranging from $0.743-0.924[1,6,7,14]$.

Note scientifique sur les caractéristiques du miel de thym de l'île grecque de Cythère.

Eine wissenschaftliche Notiz über die Eigenschaften des Thymianhonig von der griechischen Insel Kithira.

\section{REFERENCES}

[1] Aldcorn D.L., Wandler E., Sporns P., Diastase $(\alpha$ - and $\beta$-amylase) and $\alpha$-glucosidase (sucrase) activity in western Canadian honeys, Can. Inst. Food Sci. Technol. 18 (1985) 268-270.

[2] Bakandritsos N., Mallios I., Zoutsou P., Manatos N., Physicochemical parameters of greek honey, in: Proc. Natl. Conf. of Greece About Honey, Gerakini Chalkidiki, 1993 , pp. 139-164 (in Greek).

[3] Bogdanov S., Martin P., Lullmann C., Harmonised methods of the European Honey Commission, Apidologie Suppl. (1997) 1-59.

[4] Crane E., The flowers honey comes from, in: Crane E. (Ed.), Honey, A Comprehensive Survey, Heinemann, London, 1979, pp. 3-76.

[5] Drimjias N., Karabournioti S., Characteristics of Greek Thymus honey, Apiacta 30 (1995) 33-39.

[6] Dustmann J.H., Praagh J.P. van, Bote K., Zur Bestimmung von Diastase, Invertase und HMF in Honig, Apidologie 16 (1985) 19-30.
[7] Huidobro J.F., Santana F.J., Sanchez M.P. Sancho M.T., Muniategui S., Simal-Lozano J., Diastase, invertase and $\alpha$-glucosidase activities in fresh honey from north-west Spain, J. Apic. Res. 34 (1995) 39-44.

[8] Karabournioti S., Drimjias N., Some physicochemical characteristics of Greek monofloral honeys, Apiacta 32 (1997) 44-50.

[9] Louveaux J., Maurizio A., Vorwohl G., Methods of melissopalynology, Bee World 59 (1978) 139-157.

[10] Maurizio A., Microscopy of honey, in: Crane E. (Ed.), Honey, A Comprehensive Survey, Heinemann, London, 1979, pp. 240-257.

[11] Persano Oddo L., Piazza M.G., Accorti M., Diagnosis of unifloral honeys. I Present knowledge and problems, Apicoltura 4 (1988) 1-11.

[12] Persano Oddo L., Baldi E., Accorti M., Diastatic activity in some unifloral honeys, Apidologie 21 (1990) 17-24.

[13] Persano Oddo L., Piazza M.G., Sabatini A.G., Accorti M., Characterization of unifloral honeys, Apidologie 26 (1995) 453-465.

[14] Persano Oddo L., Piazza M.G., Pulcini P., Invertase activity in honey, Apidologie 30 (1999) $57-65$.

[15] Sawyer R., The assessment of honey, in: Honey Identification, Cardiff Acad. Press, 1988, pp. 55-64.

[16] Sporns P., Plhak L., Friedrich J., Alberta honey composition, Food Res. Int. 25 (1992) 93-100

[17] Thrasyvoulou A., Manikis J., Some physicochemical and microscopic characteristics of Greek unifloral honeys, Apidologie 26 (1995) 441-452. 